\title{
COMPARING PHYSICO-CHEMICAL PROPERTIES OF OIL FIELDS OF NIGERIA AND UKRAINE
}

\author{
Olufemi Babatunde ${ }^{1}$, Sergyi Boichenko, Petro Topilnytskyy ${ }^{2}{ }^{*}$, Victoria Romanchuk ${ }^{2}$
}

https://doi.org/10.23939/chcht11.02.220

\begin{abstract}
The problem of crude oil deficit for Ukrainian refineries has been considered. To solve this problem the import of crude from Nigeria has been proposed. Physicochemical properties of Nigerian oils, namely their fractional composition, potential yield of light fractions were investigated and compared with physico-chemical characteristics of Ukrainian crude oils. The possibility of Nigerian oils processing at JSC "Ukrtatnafta" (Ukraine) was grounded.
\end{abstract}

Keywords: Nigeria, petroleum refining, physico-chemical properties, crude oil.

\section{Introduction}

Modern oil-refining industry of Ukraine involves six refineries with a total capacity of above $59 \mathrm{mln}$. tons of oil per year. The largest refineries are situated in Kremechuk, Lisichansk and Kherson.

To date the oil-refining industry of Ukraine considerably depends on import. The country has enough refineries but deficit of crude. After the "record" in 1972 (14.5 mln. tons of oil and gas condensate) oil production is steadily decreased. Recently the oil production was $3 \mathrm{mln}$. t/year ( $8 \%$ of total capacity or $1 / 5$ of home market demands).

The reasons of oil production decrease are:

- reserve depletion; drilling;

- decrease in capacity and efficiency of production

- deterioration of reserves structure (for a long period the reserves with an easiest access were extracted);

- sharp reduction of exploration. For recent 15 years no new great or medium field (with reserves of more than $10 \mathrm{mln}$. tons) was opened; the proven oil fields have insignificant reserves.

\footnotetext{
${ }^{1}$ National Aviation University,

1, Komarova Ave., office 1.402, 03058 Kyiv, Ukraine

${ }^{2}$ Lviv Polytechnic National University,

12, Bandery St., 79013 Lviv, Ukraine

*topoil@lp.edu.ua

(C) Babatunde O., Boichenko S., Topilnytskyy P., Romanchuk V., 2017
}

Therefore, the problem of involving additional quantity of crude oil suitable to produce high-quality products is very urgent [1-2]. One of the ways to solve this problem is import of oil from Nigeria.

Nowadays Nigeria is one the most important producers of light low-sulphuric crude oil. The country ranks the twelfth place in the world to supply crude oil; its oil production is $1.9 \mathrm{mln}$. barrels per day [3]. Confirmed reserves of Nigerian oil are about 35.5 bln. barrels (almost $4.8 \mathrm{bln}$. tons). The daily production may be at the level of $3.0 \mathrm{mln}$. barrels (150 mln. tons per year). There are 159 oil fields in Nigeria, including a continental shelf and the delta of Niger river. Nigeria produces several types of high-quality oil: Forcados, Escravos, Odude and Bonny.

The country has only four refineries, but even working at full capacity, they can meet just a quarter of fuel demand in Nigeria. Aircraft and ground transport suffer from lack of fuel.

The aim of the present work is to establish the possibility of processing the Nigerian crude oil at Ukrainian refineries by comparing physico-chemical characteristics of the oil fields of Ukraine and Nigeria.

\section{Experimental}

Crude oils from oil fields of Nigeria which are used to produce Brent Dated and Bonny Light commercial oils (denoted as Nigeria 1 and Nigeria 2) were compared with oils from East-Ukrainian and West-Ukrainian oil fields which are used at Ukrainian refineries. The investigations were carried out in the laboratory of JSC "Ukrtatnafta" and chemmotological centre of National Aviation University.

The most interesting for evaluation are the content of high-quality oil component, their physico-chemical and operational characteristics which provide the quality of resulting products. The main indices of physico-chemical properties were determined using standard methods for oil and petroleum products [4-12].

Fractional composition was studied according to ASTM D 86-16a [13] (Table 3), ASTM D 1160 [14] (Table 4) and method which is an analog to 
ASTM D 2887, ASTM D 5307 and ASTM D 6352 [1517]. Gas chromatograph HP 7890 was used to analyze light fractions (b.b.-623 K) with a flame ionization detector and Simdis software.

To determine the metals in crude oils Varian AA240 atom-absorption spectrometer was used [18].

Density is one of the main characteristics allowing to evaluate tentatively the chemical and fractional oil composition. Depending on this index crude oils are classified as light, medium and heavy oils [1]. The light crude oils contain more gasoline fractions and less resins and sulfur. High-quality oils are produced from this type of crude. For heavy crudes with high content of resins the special treatment methods are necessary: selective treatment by solvents, adsorbents, etc. However, heavy crudes are the best raw materials to produce bitumen. One can see from Table 1 that Nigeria 1 oil belongs to light crudes $\left(\rho_{15}^{15} \leq 0.828\right)$, Nigeria 2 oil - to medium crudes $\left(\rho_{15}^{15} \leq 0.828-0.884\right)$.

Sulfur content is one of the important technological characteristics. Depending on this value oils are classified into three classes: $1^{\text {st }}$ class - low-sulfuric oils with sulfur content from 0 to $0.5 \% ; 2^{\text {nd }}$ class - sulfuric oils with sulfur content of $0.51-1.9 \% ; 3^{\text {rd }}$ class - high-sulfuric oils with sulfur content above $1.9 \%$ [1]. The investigated Nigerian oils are low-sulfuric ones of the $1^{\text {st }}$ class $(0.37$ and $0.18 \%$ of sulfur, respectively). The East-Ukrainian oil belongs to the $2^{\text {nd }}$ class; West-Ukrainian - to the $1^{\text {st }}$ class.

The presence of sulfuric compounds (hydrogen sulfide, elemental sulfur, sour sulfur and others) is undesirable because they reduce the products quality, cause the corrosion and pollute the atmosphere while fuel burning. Sulfuric compounds poison the expensive catalysts of oil processing and create ecological problems. But if sulfur content in the resulting products is higher or lower than that in the corresponding oil, this oil should be included to the higher or lower classes. So, we determined sulfur content for every narrow fraction (Table 2).

\section{Results and Discussion}

Physico-chemical characteristics of the investigated oils are presented in Table 1.

The sulfur contents for Nigerian and Ukrainian oils are commensurable. In the jet-engine fractions it is the same for Nigeria 1 and East-Ukrainian oils; sulfur content for Nigeria 2 is some lower than for West-Ukrainian oils. In the diesel oil fractions of both Nigerian crude oils the sulfur content is lower compared with Ukrainian oils. In vacuum distillates of Nigerian oils the sulfur content is lower in comparison with Ukrainian oils, so the operation conditions of catalytic cracking unit at JSC "Ukrtatnafta" will be improved.

According to the yield of fractions to $623 \mathrm{~K}$ all oils belong to the first type [1].

Water content in Nigeria 2 oil is low $(0.3 \mathrm{wt} \%)$ and water is absent in Nigeria 1. It means that oils are easy to be transported and prepared for processing. Content of salts in them range from 2.9 to $22 \mathrm{mg} / \mathrm{l}$.

Freezing point of Nigerian oils is considerably lower than that of West-Ukrainian oils and higher than the freezing point of East-Ukrainian oils. The content of sulfuric-acid resins is lower for Nigerian oils. Engler viscosities of all oils are commensurable. Yields of gasoline and diesel oil fractions are commensurable as well.

Table 3 represents fractional composition of oils investigated according to ASTM D 86-16a.

Table 1

Characteristics of crude oils

\begin{tabular}{|c|c|c|c|c|}
\hline Index & Nigeria 1 & Nigeria 2 & East-Ukrainian & West-Ukrainian \\
\hline Weight percentage of water, wt $\%$ & - & 0.30 & 0.03 & 0.25 \\
\hline Salts content, $\mathrm{mg} / \mathrm{dm}^{3}$ & 2.9 & 21.9 & 8.2 & 40.8 \\
\hline Density at $293 \mathrm{~K}, \mathrm{~kg} / \mathrm{m}^{3}$ & 806.8 & 844.0 & 844.7 & 846.6 \\
\hline Weight percentage of sulfur, wt $\%$ & 0.37 & 0.18 & 0.87 & 0.43 \\
\hline Weight percentage of sour sulfur, wt $\%$ & 0.0097 & 0.0023 & 0.0012 & 0.0005 \\
\hline Freezing point, $\mathrm{K}$ & 255 & 273 & 244 & 286 \\
\hline Sulfuric-acid resins content, wt $\%$ & 8 & 14 & 29 & 20 \\
\hline Acidity, mg KOH per $100 \mathrm{~cm}^{3}$ & 1.77 & 4.92 & 1.33 & 3.88 \\
\hline Engler viscosity at $323 \mathrm{~K},{ }^{\circ} \mathrm{E}$ & 1.1 & 1.45 & 1.2 & 1.3 \\
\hline Content of dissoluble gases, wt $\%$ & 0.26 & 0.33 & 0.35 & 0.51 \\
\hline Yield of gasoline fraction to $453 \mathrm{~K}$, wt $\%$ & 37.0 & 19.5 & 29.5 & 22.0 \\
\hline Yield of fractions to $633 \mathrm{~K}$, wt $\%$ & 72.0 & 57.3 & 59.0 & 54.5 \\
\hline
\end{tabular}


Table 2

Sulfur content in narrow fractions of the investigated oils (wt \%)

\begin{tabular}{|c|c|c|c|c|}
\hline Fraction & Nigeria 1 & Nigeria 2 & East-Ukrainian & West-Ukrainian \\
\hline IBP-335 K & 0.022 & 0.018 & 0.005 & 0.003 \\
\hline $335-358 \mathrm{~K}$ & 0.021 & 0.004 & 0.007 & 0.005 \\
\hline $358-378 \mathrm{~K}$ & 0.019 & 0.005 & 0.006 & 0.002 \\
\hline $378-393 \mathrm{~K}$ & 0.027 & 0.012 & 0.006 & 0.004 \\
\hline $393-413 \mathrm{~K}$ & 0.035 & 0.018 & 0.009 & 0.005 \\
\hline $413-433 \mathrm{~K}$ & 0.046 & 0.019 & 0.018 & 0.020 \\
\hline $433-453 \mathrm{~K}$ & 0.046 & 0.019 & 0.035 & 0.034 \\
\hline $453-473 \mathrm{~K}$ & 0.060 & 0.024 & 0.057 & 0.049 \\
\hline $473-493 \mathrm{~K}$ & 0.055 & 0.039 & 0.079 & 0.105 \\
\hline $493-513 \mathrm{~K}$ & 0.108 & 0.047 & 0.110 & 0.184 \\
\hline 513-533 K & 0.218 & 0.058 & 0.205 & 0.238 \\
\hline 533-553 K & 0.362 & 0.070 & 0.385 & 0.362 \\
\hline 553-573 K & 0.387 & 0.081 & 0.517 & 0.433 \\
\hline 573-613 K & 0.446 & 0.130 & 0.674 & 0.810 \\
\hline 613-633 K & 0.636 & 0.182 & 0.867 & 0.501 \\
\hline 633-643 K & 0.654 & 0.210 & 0.942 & 1.833 \\
\hline Residuum & 0.974 & 0.317 & 1.089 & 1.142 \\
\hline $\begin{array}{c}\text { Vacuum distillate (residual oil } \\
\text { vacuum distillation using ARN-2) }\end{array}$ & 0.716 & 0.212 & 2.409 & \\
\hline Residuum after residual oil vacuum & 1.217 & 0.428 & & \\
\hline distillation using ARN-2 & & & &
\end{tabular}

Table 3

Fractional composition of investigated oils (IBP-633 K, vol \%)

\begin{tabular}{|c|c|c|c|c|}
\hline Temperature, $\mathrm{K}$ & Nigeria 1 & Nigeria 2 & East-Ukrainian & West-Ukrainian \\
\hline Initial boiling point & 323 & 331 & 324 & 330 \\
\hline 353 & 7.5 & 3.0 & 5.5 & 4.0 \\
\hline 373 & 12.0 & 4.0 & 11.5 & 10.0 \\
\hline 393 & 18.0 & 6.5 & 23.0 & 14.0 \\
\hline 413 & 26.0 & 10.0 & 27.5 & 18.0 \\
\hline 433 & 30.5 & 14.0 & 31.0 & 22.0 \\
\hline 453 & 35.0 & 18.5 & 34.5 & 26.0 \\
\hline 473 & 40.0 & 22.5 & 38.0 & 29.0 \\
\hline 493 & 44.5 & 27.0 & 41.0 & 32.5 \\
\hline 513 & 49.0 & 31.0 & 45.0 & 36.0 \\
\hline 533 & 53.0 & 35.0 & 49.0 & 40.0 \\
\hline 553 & 57.5 & 39.0 & 53.0 & 44.5 \\
\hline 573 & 61.5 & 44.0 & 56.0 & 49.0 \\
\hline 593 & 65.5 & 48.5 & 60.0 & 54.0 \\
\hline 613 & 69.0 & 53.0 & 62.5 & 56.0 \\
\hline 623 & 70.5 & 56.0 & 65.0 & 57.0 \\
\hline 633 & 72.5 & 58.0 & & \\
\hline
\end{tabular}

Table 4

Fractional composition of investigated oils (fraction > 643 K, vol \%)

\begin{tabular}{|c|c|c|c|c|}
\hline Temperature, $\mathbf{K}$ & Nigeria 1 & Nigeria 2 & East-Ukrainian & West-Ukrainian \\
\hline Initial boiling point & 643 & 653 & 643 & 646 \\
\hline 693 & 18.4 & 7.3 & 12.7 & 17.2 \\
\hline 703 & 23.9 & 15.4 & 17.0 & 22.6 \\
\hline 713 & 30.5 & 22.1 & 21.1 & 27.5 \\
\hline 723 & 36.0 & 28.4 & 25.9 & 32.1 \\
\hline 733 & 41.2 & 34.0 & 30.1 & 36.5 \\
\hline 743 & 46.0 & 39.0 & 34.3 & 40.8 \\
\hline 753 & 50.8 & 43.6 & 38.3 & 44.8 \\
\hline 763 & 54.7 & 47.8 & 41.6 & 52.1 \\
\hline 773 & 58.6 & 51.7 & 43.7 & 56.0 \\
\hline 783 & 62.2 & 55.5 & 46.8 & 57.5 \\
\hline
\end{tabular}


Table 5

Total yield (wt \%) of the fractions (TBP)

\begin{tabular}{|c|c|c|c|c|}
\hline Temperature, K & Nigeria 1 & Nigeria 2 & East-Ukrainian & West-Ukrainian \\
\hline$<342$ & 2.8 & 2.6 & 1.7 & 1.4 \\
\hline 353 & 8.0 & 4.4 & 6.0 & 3.5 \\
\hline 363 & 12.0 & 5.9 & 9.5 & 5.5 \\
\hline 373 & 15.0 & 7.3 & 12.5 & 8.0 \\
\hline 383 & 18.0 & 8.6 & 15.5 & 10.0 \\
\hline 393 & 21.0 & 10.0 & 18.0 & 11.5 \\
\hline 403 & 23.0 & 11.5 & 20.0 & 13.0 \\
\hline 413 & 26.0 & 13.1 & 22.0 & 14.5 \\
\hline 423 & 29.0 & 14.8 & 24.0 & 16.5 \\
\hline 433 & 32.0 & 16.4 & 26.0 & 18.5 \\
\hline 443 & 34.5 & 17.9 & 28.0 & 20.0 \\
\hline 453 & 37.0 & 19.5 & 29.5 & 22.0 \\
\hline 463 & 39.5 & 21.2 & 31.0 & 23.5 \\
\hline 473 & 42.0 & 22.7 & 32.5 & 25.0 \\
\hline 483 & 44.0 & 24.4 & 34.0 & 26.5 \\
\hline 493 & 46.5 & 26.3 & 36.0 & 28.0 \\
\hline 503 & 48.5 & 28.0 & 37.5 & 29.5 \\
\hline 513 & 50.5 & 30.1 & 39.0 & 31.5 \\
\hline 523 & 53.0 & 31.9 & 41.0 & 33.5 \\
\hline 533 & 55.0 & 33.8 & 42.5 & 35.5 \\
\hline 543 & 57.0 & 36.0 & 44.5 & 37.0 \\
\hline 553 & 59.0 & 38.4 & 46.0 & 39.0 \\
\hline 563 & 61.0 & 40.7 & 48.0 & 41.0 \\
\hline 573 & 62.5 & 42.8 & 49.5 & 43.0 \\
\hline 583 & 64.0 & 45.0 & 51.0 & 45.0 \\
\hline 593 & 66.0 & 47.7 & 53.0 & 47.5 \\
\hline 603 & 67.5 & 50.3 & 54.5 & 49.0 \\
\hline 613 & 69.0 & 52.9 & 56.0 & 51.0 \\
\hline 623 & 71.0 & 55.0 & 57.5 & 53.0 \\
\hline 633 & 72.0 & 57.3 & $\mathbf{5 9 . 0}$ & 54.5 \\
\hline 643 & 73.5 & 58.8 & 60.5 & 56.5 \\
\hline 653 & 75.0 & 60.3 & 62.0 & 58.0 \\
\hline 663 & 76.5 & 62.3 & 63.5 & 60.0 \\
\hline 673 & 78.0 & 63.8 & 65.0 & 62.0 \\
\hline 683 & 79.0 & 64.3 & 66.5 & 64.0 \\
\hline 693 & 80.5 & 65.3 & 68.0 & 65.5 \\
\hline 703 & 82.0 & 67.8 & 69.5 & 68.0 \\
\hline 713 & 83.5 & 70.3 & 71.0 & 70.0 \\
\hline 723 & 85.0 & 73.0 & 72.5 & 72.0 \\
\hline 733 & 86.0 & 75.0 & 74.0 & 73.5 \\
\hline 743 & 87.5 & 77.0 & 75.5 & 75.5 \\
\hline 753 & 88.5 & 79.0 & 76.5 & 77.5 \\
\hline 763 & 90.0 & 80.5 & 78.0 & 79.0 \\
\hline 773 & 91.0 & 82.0 & 79.0 & 80.5 \\
\hline 783 & 92.0 & 84.0 & 80.5 & 82.0 \\
\hline 793 & 93.5 & 85.0 & 81.5 & 83.0 \\
\hline 803 & 95.0 & 86.0 & 83.0 & 85.0 \\
\hline 813 & 95.6 & 86.7 & 83.5 & 85.7 \\
\hline Residue $>813 \mathrm{~K}$ & 4.4 & 13.3 & 16.5 & 14.3 \\
\hline
\end{tabular}


The total yield of the fractions of investigated oils is represented in Table 5 .

The residual oil (> $643 \mathrm{~K}$ ) was distilled according to ASTM D 1160, the results are presented in Table 4.

According to the results of atmospheric distillation Nigeria 1 is a light oil with IBP $323 \mathrm{~K}$. Nigeria 2 is a heavier oil with IBP of $331 \mathrm{~K}$. For Nigeria $137 \mathrm{wt} \%$ of the fractions are boiled to $453 \mathrm{~K}$; for Nigeria $2-19.5 \%$. These values indicate the potential content of gasoline fractions and are commensurable with those for Ukrainian oils (29.5 and $22 \mathrm{wt} \%$ for East- and West-Ukrainian oils, respectively). The potential content (wt \%) of diesel oil fractions: Nigeria 1 - 35; Nigeria 2 - 37.8; East-Ukrainian - 29.5; West-Ukrainian - 32.5. The yield of jet-engine fractions of Nigeria 1 and 2 oils is 24.5 and $17.0 \mathrm{wt} \%$, respectively, that is essentially higher than the analogous yield of Ukrainian oils. The yield of wide oil fractions $633-813 \mathrm{~K}$ is 23.6 and $29.4 \mathrm{wt} \%$ for Nigerian oils, respectively; 24.5 and $31.2 \mathrm{wt} \%$ for Ukrainian oils, respectively.

Microelemental composition of crude oil is an important characteristic providing geologic-geochemical information about oil age, ways of its migration and accumulation. There are about 60 microelements in the crude oil [19-22].

Metals in crude oil considerably affect the oil processing, including catalysts poisoning, equipment corrosion and ingress into resulting products. It is known that metals concentration in crude oils varies within wide range and their average values are reduced from $n \cdot 10^{-3}$ to $n \cdot 10^{-8}$ wt $\%$ in the series: $\mathrm{V}, \mathrm{Fe}, \mathrm{Ca}, \mathrm{Ni}, \mathrm{Na}, \mathrm{K}, \mathrm{Mg}, \mathrm{Al}$, $\mathrm{Hg}, \mathrm{Zn}, \mathrm{Mo}, \mathrm{Cr}, \mathrm{Cu}, \mathrm{Co}, \mathrm{Mn}, \mathrm{Ba}, \mathrm{Ge}, \mathrm{Ag}, \mathrm{Hf}, \mathrm{Pb}, \mathrm{Au}, \mathrm{Be}$, $\mathrm{Ti}, \mathrm{Sn}$.
Moreover, metal content is regulated by technological regulations, namely $\mathrm{Cu}$ content - for raw material (gasoline fractions) of reforming, isomerization, etc.; $\mathrm{V}, \mathrm{Ni}$ and $\mathrm{Fe}$ content - for raw material (vacuum gas oils and residues) of catalytic cracking and hydrofining.

Metals are mostly concentrated in resinousasphaltenic compounds (RAC) of crude oil. Vanadium in the form of vanadyl-porphyrin complexes in the amount of $10^{-5}-10^{-2} \%$ is concentrated in RAC being the cause of equipment strong corrosion and environment poisoning due to the formation of vanadium oxide while residuum burning. Vanadium content (ppm) in Nigeria 1 oil is 0.24 ; Nigeria 2 - 1.28; West-Ukrainian - 1.91 and EastUkrainian - almost 11 (Table 6). The amount of vanadium is associated with sulfuric compounds, because vanadium promotes the sulfates reduction to hydrogen sulfide and sulfur. Thus, East-Ukrainian oil has the maximum amount of vanadium and sulfur (11 ppm and $0.87 \%$, respectively).

Nickel is also concentrated in RAC in the amount of $10^{-4}-10^{-3} \%$ but in a small amount it is also presented in oil fractions of heavy oil. The same as vanadium, nickel is in the form of vanadyl-porphyrin complexes. Its amount in Nigeria 1 and 2 is 0.18 and 3.18 ppm, respectively; in East- and West-Ukrainian oils - 10.99 and $3.67 \mathrm{ppm}$, respectively.

Iron is presented in crude oils in a small amount. It is distributed within the whole range of boiling temperatures. The nature of iron compounds is studied insufficiently but it is expected that $\mathrm{Fe}$ is also in the form of porphyrin complexes. The highest amount of iron (41.35 ppm) was found to be in East-Ukrainian oil. In other samples its amount is relatively low $(2.96,1.3$ and $4.6 \mathrm{ppm})$.

Table 6

Metals content in the investigated oils $(\mathrm{mg} / \mathrm{kg})$

\begin{tabular}{|l|c|c|c|c|}
\hline \multicolumn{1}{|c|}{ Metal } & Nigeria 1 & Nigeria 2 & East-Ukrainian & West-Ukrainian \\
\hline Iron & 2.96 & 1.3 & 41.35 & 4.6 \\
\hline Zinc & 0.72 & 0.38 & 4.21 & 1.79 \\
\hline Nickel & 0.18 & 3.18 & 10.9 & 3.67 \\
\hline Vanadium & 0.24 & 1.28 & 10.99 & 1.91 \\
\hline Copper & 4.73 & 0.08 & 0.59 & 0.1 \\
\hline Manganese & not detected & not detected & 0.13 & 0.21 \\
\hline Chrome & not detected & not detected & 0.22 & 0.07 \\
\hline Calcium & 6.52 & 5.07 & 1.64 & 7.47 \\
\hline Magnesium & 2.05 & 1.27 & 1.17 & 5.91 \\
\hline Sodium & 5.77 & 6.05 & 10.14 & 58.49 \\
\hline Potassium & 0.63 & 0.36 & 0.43 & 0.92 \\
\hline Cobalt & 0.15 & not detected & not detected & not detected \\
\hline Lead & not detected & 0.1 & 0.59 & not detected \\
\hline Barium & not detected & not detected & 0.25 & 14.6 \\
\hline Molybdenum & 0.02 & 0.841 & 0.11 & trace \\
\hline Aluminium & not detected & 2.346 & 6.44 & 3.42 \\
\hline Silicium & 0.24 & 5.752 & 1.48 & 0.25 \\
\hline
\end{tabular}


The share of alkali and alkaline earth metals (sodium, potassium, magnesium, calcium) is $10^{-3}-10^{-4} \%$. These elements are part of stratal water. Even the most careful treating is not able to purify crude oil from the mentioned microimpurities. All alkali and alkaline earth metals in the form of petroleum acid salts, phenolates, thiophenolates, etc. are present in all fractions. Among all alkaline earth metals, which were found in the studied oils, sodium has the highest share. Its concentration in West-Ukrainian oil is 58.49 ppm, in East-Ukrainain almost 6 times less (10.14 ppm). In Nigerian oils sodium is present in small amounts -5.77 and $6.05 \mathrm{ppm}$. The content of calcium in the Nigerian oils is commensurable with East-Ukrainian oils (5-7 ppm); its smallest content is in West-Ukrainian oil (1.64 ppm). Potassium content is insignificant in all investigated samples - less than $1 \mathrm{ppm}$. Copper is presented in all samples, the highest amount in Nigeria 1. In other oils copper content is less than $1 \mathrm{ppm}$.

\section{Conclusions}

Two Nigerian crude oils were compared with the mixtures of East-Ukrainian and West-Ukrainian oils. We found the similarity of oils by their fractional composition but the yield of gasoline and diesel oil fractions of Nigeria 1 is considerably higher than those values of other oils. Nigerian oils are low-sulfuric oils, having a low freezing point and low content of sulfuric-acid resins. The yield of jet-engine fractions from Nigeria oils is considerably higher than that from Ukrainian oils; the yield of oil fractions is commensurable. The content of vanadium, iron, nickel and sodium in Nigerian oils is essentially higher than in Ukrainian oils.

On the basis of data about fractional composition, content of sulfuric compounds and sulfuric-acid resins, freezing point, viscosity, content of heavy metals we may assert that Nigerian oils Brent Dated and Bonny Light may be processed at JSC "Ukrtatnafta" without any changes in the process flowsheet and regimes.

The physico-chemical analysis of Nigerian oils allows to propose the scheme of oil processing for Nigerian refineries.

\section{References}

[1] Topilnytskyy P., Hrynyshyn O., Machynskyy O.: Technologia Pervynnoi Pererobky Nafty i Gazu. Vydav. Lvivska Polytechnika, Lviv 2014.

[2] Boichenko S., Cherniak L., Novikova V. et al.: Control Yakosti Palyvno-Mastylnykh Materialiv. Nats. Aviats. Univ., Kyiv 2012. [3] http://oilreview.kiev.ua/2016/12/08/105241/
[4] ASTM D1298-12b Standard Test Method for Density, Relative Density, or API Gravity of Crude Petroleum and Liquid Petroleum Products by Hydrometer Method

[5] ASTM D3230-13 Standard Test Method for Salts in Crude Oil (Electrometric Method)

[6] ASTM D4928-12 Standard Test Method for Water in Crude Oils by Coulometric Karl Fischer Titration

[7] ASTM D4294 Determination of Sulfur content in Petroleum and Petroleum Products by Energy-Dispersive X-ray Fluorescence Spectrometry

[8] UOP 163-05 Hydrogen Sulfide and Mercaptan Sulfur in Liquid Hydrocarbons by Potenciometric Titration

[9] ASTM D323-99 Standard Test Method for Vapor Pressure of Petroleum Products (Reid Method)

[10] ASTM D974-93 (02e1) Standard Test Method for Acid and Base Number by Color-Indicator Titration

[11] ASTM D525-95 (-00) Standard Test Method for Oxidation Stability of Gasoline (Induction Period Method)

[12] ASTM D381-86 (-99) Standard Test Method for Gum Content in Fuels by Jet Evaporation

[13] ASTM D86-16 Standard Test Method for Distillation ofPpetroleum Products at Atmospheric Pressure

[14] ASTM D1160 Standard Test Method for Distillation of Petroleum Products at Reduced Pressure

[15] ASTM D2887 Standard Test Method for Boiling Range Distribution of Petroleum Fractions by Gas Chromatography

[16] ASTM D5307-97 (Reapproved 2002)e1 Standard Test Method for Determination of Boiling Range Distribution of Crude Petroleum by Gas Chromatography

[17] ASTM D6352-04e1 Standard Test Method for Boiling Range Distribution of Petroleum Distillates in BoilingRange from 174 to $700^{\circ} \mathrm{C}$ by Gas Chromatography 1 .

[18] ASTM D5056-15 Standard Test Method for Trace Metals in Petroleum Coke by Atomic Absorption

[19] Kolodiazhnyi A., Kovalchuk T., Korovin Yu., Antonovych V.: Metody i Obiekty Khim. Sinteza, 2006, 1, 90.

[20] Nadirov N., Kotova A., Kamianov V.: Metaly v Neftiakh. Nauka, Alma-Aty, 1984.

[21] Mir-Babaev M.: Khimiya Topliv i Masel, 1997, 5, 46.

[22] Aleshin G., Samedova F., Mir-Babaev M., Kamianov V.: Neftekhimiya, 1990, 30, 175.

Received: December 13, 2016 / Revised: February 02, 2017 / Accepted: February 22, 2017

\section{ПОРІВНЯННЯ ФІЗИКО-ХІМІЧНИХ ВЛАСТИВОСТЕЙ НАФТ РОДОВИЩ НІГЕРІЇ ТА УКРАЇНИ}

\begin{abstract}
Анотація. В статті розглянута проблема нестачі нафти для нафтопереробних заводів Украйни. Одним з виходів з даної ситуачії пропонується імпортування нафти з Нігерії. Наведені результати із дослідження фізико-хімічних показників нігерійських нафт, їх фракиійної розгонки, потениійного виходу світлих фракцій; отримані дані порівнюються з фізикохімічними характеристиками нафт східно- та західноукраӥнських родовищ. Обгрунтована можливість перероблення нігерійських нафт на ПАТ «Укртатнафта» (Украӥна).
\end{abstract}

Ключові слова: Нігерія, нафтоперероблення, фізикохімічні показники, нафта. 